\title{
Evaluation Models of Guidance and Counseling Service Based CIPP in Senior High School
}

\author{
Sugiyo, Muslikah \\ Universitas Negeri Semarang, Semarang, Indonesia \\ e-mail: sugiyo@mail.unnes.ac.id
}

\begin{abstract}
This research specifically aimed to develop the evaluation models of guidance and counseling service based CIPP in school. This research included as the kind of research and development. The used technique to collect the data in this development research of models consist questionnaire expert judgment and FGD (focused group discussion). This FGD activity involves counselor and supervisor of guidance and counseling in SMA in Semarang city. The structure model of evaluation of guidance and counseling service based CIPP to be: (a) rational, (b) definition, (c) purpose, (d) assumption, (e) intervention target, (f) steps, (g) competency and role of school counselor and (h) system support. Based on Wilcoxon analysis, Zcalculation was reach 3,18 whereas Z-table with significance level 5\% got Z-table 1,96. So, the value of Zcalculation $>$ Z-table and can be assumed that evaluation models of guidance and counseling service based CIPP was effective developed to increase the competency of counselor in evaluation service of guidance and counseling. Therefore counselor can take a decision accurately about changes which must be done in order to increase the quality of guidance and counseling in school. For the next research, socialization and training of evaluation models of guidance and counseling which is based CIPP needs to be followed-up with the program of matter refreshment and techniques in more effective implementation.
\end{abstract}

Keywords: evaluation model of guidance and counseling service, CIPP

\section{INTRODUCTION}

The whole process of guidance and counseling management must be completed with accountability maintenance. It is because accountability has important role in guidance and couseling service in school (Gysbers, 1995; Gysbers \& Handerson, 2006). Cobia and Handerson (2007) explained that accountability is an effort from counselor to show stakeholder and client regarding what he has done to increase the students achievement in academic field. The maintenance of accountability can be done only if the counselor implements the evaluation of his finished guidance and counseling programs (Cobia \& Handerson, 2003; Sink, 2009). Based on the evaluation results, counselor is able to appraise the effectiveness of his finished guidance and counseling programs. Furthermore, these evaluations results have to be publicated as a form of responsibility (accountability). This accountability is very important because counselor will use many resources from society to serve his profession.

Unfortunately most of the practice of guidance and counseling service, evaluation and accountability of its guidance and counseling in school are wrongly implemented. The study from Sugiyo (2010) about counselor competence in evaluating the program shows that counselor rarely does this evaluation. Guidance and counseling program which produced by certain counselor is found and used for several years indiscriminately. The usage of guidance and counseling is kind of repetitive without any evaluation of its weakness and its relevance with the student requirements. Similarly, the result of Sugiyo and Sunawan research (2012) found that all counselor (100\%) and 
school headmaster said that evaluation toward guidance and counseling service was very important for program development $(40,90 \%)$ and so do the raising of counselor competence $(27,27 \%)$. However not all counselors do the evaluation of guidance and counseling service $(18,18 \%)$, whereas the rest of them do the evaluation periodically $(59,09 \%)$ and unperiodically $(22,72 \%)$.

The implication of these facts is the urgent needs of counselor evaluation models which enable counselor to get information about the impact of his given service. This research is specifically directed to develop the evaluation model of guidance and counseling in school which based on CIPP. Through this evaluation model of guidance and counseling service in senior high school which is based on CIPP, the counselor is expected to be assisted in evaluating his implemented guidance and counseling programs, so that they finally can contribute in the escalation of counselor competence.

Fitzpatrick, Sanders and Worthen (2004) clasified the types of evaluation to context, input, process and product (CIPP) as the models of evaluation which oriented in management. In this case, it can be known whether CIPP evaluation model is a relevant evaluation model to the requirements of guidance and counseling service in school.

Based on the explanation from Stufflebeam and Shinkfield (in Fitzpatrick, Sanders \& Worthen, 2004); Stafflebeam (1999, 2003); and Tayibnapis (2008), evaluation in CIPP model is done in four processes of management: context, input, processand product.

Context evaluation is conducted to describe the implemented program context, identify the requirements of all person involved in program, diagnose the basic requirement and arrange the aim of program. The implementation of context evaluation can be done using survey method, interview, documen analysis and diagnostic test. The important decision that can be taken as result of context evaluation is the aim of program which is directed to fulfill personal requirement, solve the problem and the expected change.

Input evaluation is implemented to identify and detect the system support or competence, the alternative program strategy, procedure design of program implementation, cost management and the schedule of program. Input evaluation methods are inventaris and analysis human resources and materials, literature study, comparative study and advocate team. Input evaluation can result in the decision about choosing the supporting resources, problem solving strategy, procedure design and the basic information of program implementation.

Process evaluation done to identify or predict the processes which hamper procedure design or its implementation, record and appraise the implemented procedure of activity and serve the parts of information to arrange the program in the future. The usable methods in program evaluation are by controlling the hamper potencies of procedure implementation, anticipating the unpredicted circumstation, describing the program implementation process and observating.The decision that can be taken from process evaluation are reparation and implementation of program and procedure, field note (log) of program implementation in order to interpretating the program succes.

Product evaluation is held to collect the description and appraisal ragarding achieved result and compare it with the purpose, information of context, input and process; interpreting the excellent appraise from program. The usable methods in product evaluation are by describing the result criterion which to be achieved, collecting the appraisal of program result from stakeholder and analysing qualitatively and also qualitatively. Several decisions that can be taken from product evaluation are continuing, dismissing, modifying or re-focusing the program design.

\section{METHOD}

This research belongs to research and development (Gall, \& Borg, 2007). The definitions about this research are as following:

1) Arranging the hypothesis model design

2) Validating the hypothesis model design by doing model validation from the expert and validating the practice of model through Focus Group Discussion which involves counselor in senior high school(15 school counselors inSemarang city) and supervisor of senior high school counselor in Semarang city.

3) Revision the hypothesis model design

4) Fit and proper test throgh steps: giving _pretest, training and socialiszation of evaluation model of guidance and counseling service based CIPP toward school counselor and supervisor of senior high school counselor and post-test. 
5) The step of product test, so that the evaluation model of guidance and counseling service which based CIPP had been arranged well

This research involves two groups, they are the subject and the team of expert. This subject is involved in the activity of content validity appraisal of evaluation hypothesis guidance and counseling service in senior high school based on CIPP. The subject of expert team delegate two persons from guidance and counseling sector. They are from guidance and counseling department of Universitas Negeri Semarang (UNNES) they are Prof. Dr. DYP Sugiharto, M.Pd, Kons dan Prof. Dr. Mungin Eddy Wibowo, M.Pd, Kons.

Second, the subject team which involved in the activity of model practice validity through Focus Group Discussions teacher whom given the socialization and training of CIPP model. They are school counselor and counselor supervisor in senior high school in Semarang city. The subject group consists of fifteen school counselors from ten senior high schools in Semarang city from state or nonstate and one counselor senior high school supervisor in Semarang city.

There are techniques which used in model feasibility analysis:

1. Model rational test which involves the expert of guidance and counseling

2. Model accuracy test which involves school counselor and school counselor supervisor

3. Model practicality test by doing Focus Group Discussion with practitioner or school counselor

Whereas model effectivity test in this research is Wilcoxon test, andthe used scale is degree scale. Therefore the formula is as follows:

Formula of Wilcoxontest (Sugiyono, 1996:133)

$$
\mathrm{z}=\frac{T-\mu_{T}}{\sigma T}=\frac{T-\frac{n(n+1)}{4}}{\sqrt{\frac{n(n+1)(2 n+1)}{24}}}
$$

Description:

$$
\begin{array}{ll}
\mathrm{T} & =\text { the amount of small level } \\
\mathrm{n} & =\text { the amount of sample }
\end{array}
$$

The result of calculation had been consultated with wilcoxon table index. If the result of analysis is bigger than wilcoxon table index, it means CIPP model reputed as an effective way to develop the competence of guidance and counseling service evaluation.

\section{RESULT AND DISCUSSION}

The structure of evaluation model guidance and counseling service in senior high school based on CIPP consists of: (a) rational (b) model concept (c) purposes (d) assumption (e) intervention target (f) steps (g) competence and role of school counselor (h) system support.For more specific description, the structure of the aforementioned model is described as:

\subsection{The rational evaluation model of guidance and counseling service in senior high school based CIPP}

The whole process of guidance and counseling management must be completed with the upholding of accountability because it has the important role in guidance and counseling service in school (Gysbers, 1995; Gysbers \& Handerson, 2006). Cobia and Handerson (2007) explained that accountability is the counselor's efforts to exhibit client and stakeholder regarding what he does to increase the success of his students. The upholding of accountability only can be done if counselor implements the evaluation of his programs. (Cobia \& Handerson, 2003; Sink, 2009). Based on evaluation results, counselor is able to appraise the effectivity of his finished guidance and counseling programs. Then its evaluation results have to be delivered to society as a form of responsibility (accountability). This accountability is very important because counselor has used many resources from society to run his profession.

However, in guidance and counseling practice in senior high school, many evaluation and accountability of guidance and counseling program have not been well implemented yet.

The exsistance of incorrect public overview toward counselor duties, is a kind of indicator if the accountability of guidance and counseling has not been upholded yet. Most people still consider that school counselor is kind of the school police; guidance and counseling is about advise giving; guidance to make student become discipline and school counselor seems like psychiatrist (Munandir, 2005; Prayitno, 1987).

The study from Sugiyo (2010) about counselor competence in evaluating the program shows that 
counselor do this evaluation rarely. Guidance and counseling program which produced by counselor is inclined and then used for several years. The usage of guidance and counseling is kind of repetitive without any evaluation of its weakness and its relevance with the student requirements. Similarly, the result of Sugiyo and Sunawan research (2012) found that all counselor (100\%) and school headmaster said if evaluation toward guidance and counseling service was very important for program development $(40,90 \%)$ and so do the raising of counselor competence $(27,27 \%)$. However, not all counselor do the evaluation of guidance and counseling service $(18,18 \%$ ), whereas the rest of them do the evaluation periodically $(59,09 \%)$ and unperiodically $(22,72 \%)$.

The evaluation model of guidance and counseling based on the study from Sugiyo and Sunawan (2012) ought to havethe following characteristics: has the evaluation model instrument of guidance and counseling (54,55\%), appropriate with the exists guidance and counseling curriculum $(31,82 \%)$, has the endorser software $(27,27 \%)$ and serve kinds of endorser format of guidance and counseling evaluation process $(22,73 \%)$.

The guidance and counseling evaluation model development in this research specifically based on CIPP evaluation model (context, input, process, product) (Stufflebeam, 1999, 2003). The selection of CIPP as basic evaluation model is because CIPP has an evaluation model which focus on evaluation to each management processes (Fitzpatrick, Sanders \& Worthen, 2004).

The evaluation based on CIPP in guidance and counseling service setting in school enables the counselor to appraise whole management process of guidance and counseling, starts from requirements assesment until the appraisal of guidance and counseling service effects. Based on the results of appraisal in each management processes, counselor is able to take a decision about changes that should be done accurately in order to develop the high quality service of guidance and counseling in school.

This evaluation model which is being developed is expected to be able to motivate counselor to uphold the accountability of guidance and counseling services. Therefore, counselor is able to show toward clients and stakeholder about counselor works and its functions for students and school.

\subsection{Evaluation model of guidance and counseling service in senior high school based CIPP}

The CIPP (context, input, process and product) evaluation model is a kind of evaluation model which focuses on management. From this overview, it can be understood if CIPP evaluation model is a relevant evaluation model to the requirements of guidance and counseling evaluation model in school. The evaluation in CIPP model consists of four management processes, they are context, input, process and product.

\subsection{The purposes of evaluation modeling guidance and counseling service in senior high school based CIPP}

The purposes of evaluation model in guidance and counseling service in senior high school based on CIPP are:

1. Repair the competence of counselor in giving the guidance and counseling service

2. Increase the accountability of guidance and counseling service in senior high school

3. Help the counselor to make the betterment of program and implements the guidance and counseling service in senior high school

\subsection{The assumptions of evaluation model in guidance and counseling service in senior high school based CIPP}

The assumptions which have been used as basic parameter to create the evaluation model of guidance and counseling service in senior high school are:

1) The evaluation ought to has the purposes to repair (to improve) not to prove (to prove). So, evaluation should able to make an improvement, increase the accountability and the entire understanding and preview toward a program.

2) The evaluation which based CIPP in a setting of guidance and counseling service in school enable the counselor to appraise the whole management processes of guidance and counseling, starts from the requirements assesment until the appraisal of guidance and counseling service effects.

3) A good evaluation is a step which entire and systematically. Therefore CIPP model is an 
evaluation model which is oriented in a relevant management with the requirements of evaluation model of guidance and counseling service in school.

\subsection{The target of intervention evaluation model of guidance and counseling service in senior high school based on CIPP.}

The main target of intervention is to help counselor in developing the accountability of guidance and counseling service in senior high school. Then the specific intervention target is to facilitate the counselor and supervisor of guidance and counseling service in making the plan of counselor competence development.

\subsection{Steps of implementation the operating evaluation model of guidance and counseling in senior high school based on CIPP.}

Steps of implementation the operating evaluation model of guidance and counseling in senior high school based CIPP cover four management processes, there are context, input, process and product as follows:

\section{Context Evaluation Step}

The main context orientation is to identify the weakness and excession of guidance and counseling service. For more detail, the things that counselor have to do in context evaluation are evaluations which consists of several questions that must be answered are:

a. Regarding the program purposes

b. Why should the program made

c. Is it relevant with vision and mission of the institution?

d. Is the program arranged considered the availability of fund?

e. Is the purposes formulated specifically?

f. Is the program purposes suitable with environment requirements?

\section{Input Evaluation Step}

The main orientation in input evaluation is to help determining the program which carries the entire changes needed. Specifically in inputing evaluation steps which have to be done by counselor is evaluation which consists of several questions that need to be answered as follows:

a. Regarding the used input to fulfill process in achieving the purpose

b. If the purpose had achieved, is the purpose already appropriate?

c. How is the input quality?

d. Where is the sources of input?

e. How much is the cost?

f. Who are involved in its process?

g. How is the qualification and competence?

\section{Process Evaluation Step}

The main orientation of process evaluation is to evaluate the finished tasks to see whether the program is appropriate with the planned stategies or not. Specifically in process evaluation the counselor has to evaluate.This evaluation consists of several questions, they are:

a. Regarding the activities of program plan implementation with the served input

b. When will the program be held?

c. How is the procedures of program implementation?

d. How is the cooperation with involved parties?

e. Is the program operated suitably with the arranged schedule?

f. Are all input support the process of program implementation?

g. What is the weakness of program implementation?

\section{Product Evaluation Step}

The main orientation of product evaluation is an evaluation which aimed to measure, interpretate and appraise the achieved program and connect it with outcame with context, input and process. Specifically in product evaluation step, counselor has to evaluate with several questions:
a. Regarding the result achieved
b. How far is the program purpose achieved
c. What program which achieved with high/low result
d. How is the level of people satisfaction whom involved in program
e. Is the program achieved in time?
f. What is the negative/positive impacts of program
g. Is the programm requires to be continued/revised/discontinued 


\section{g. School counselor role and competence}

The models implementation of evaluation model of guidance and counseling service in senior high school based on CIPP requires several competences from school counselor:

1) Open minded. School counselor is expected to have an open mindset, moreover regarding with the CIPP model.Evaluation is a systematic and the entire process must be done continuously.

2) Understanding the concept and procedure in evaluating CIPP model.

3) Able to implement CIPP model which is suitable with the requirements in order to increase the quality of guidance and counseling service.

Whereas school counselor roles in CIPP model implementation are:

1) In context evaluation, school counselor identifying the weakness and excessness of guidance and counseling service

2) In input evaluation, school counselor helps determining the program which will bring to the alteration required

3) In process evaluation, school counselor controls the program implementation is suitable with the planned strategies or not

4) In product evaluation, school counselor measures, interpretates and appraises the achieved program and connects to the outcome with context, input and process.

5) School counselor does the follow up or repair (to improve) the low guidance and counseling service.

\section{h. System Support}

Evaluation model of guidance and counseling in senior high school which is based on CIPP in order to make it become more optimal needs the supports from all stakeholder in school such as headmaster, counselor supervisor and students. These supports mean to make school stakeholder understand the importance of guidance and counseling evaluation service until the skill of counselor can be optimal.

Beside that, considered from the system supports which exist evaluation model of guidance and counseling service based on CIPPis expected to be able to develop the qualified guidance and counseling program and develop the professional guidance and counseling staff, and it requires the goverment support and profession association in policy making of evaluation model of guidance and counseling based CIPP.

In producing model of guidance and counseling service based CIPP which effectively tested, the beginning stepto do is to test the feasibility of model rationally. The model feasibility test rationally done through the appraisal from expert (expert judgment). The validation of model rationality done through the consultation with guidance and counseling expert in this case they are Prof. Dr. DYP Sugiharto, M.Pd, Kons. and Prof. Dr. Mungin Eddy Wibowo, M.Pd., Kons. and practicioner (such as school counselor and counselor supervisor).

The validation of model rationality done by using detailed response technique. Researchersdeliver model which completed with research instrument that formed scale (quantitative data) and suggestions/inputs (qualitative data). Commonly, the expert appraise content which regards rationality, explanation, purpose, assumption, intervention target, model component, steps, competence, matter, evaluation and succes indicator. Generally, the expert explains if model is already feasible to be implemented to test the effectivity.

Whereas the result of focus group discussion (FGD) and practicioner validation with school counselor and counselor supervisor in senior high school in Semarang city concluded as:

1) Generally CIPP model is already suitable with target, simple and practicable and also understandable

2) This model is good and ready to be implemented in school, but still requires an illustration and introduction in each instrument of CIPP evaluations to make the filling understanding become easier.

3) Requires workshop and socialiszation/introduction and also training specifically for school counselors in senior high school in order to make school counselor become easier in understanding CIPP.

4) School counselor in field needs instrument of evaluation to appraise process and result of service done based on requirements of competence fulfillment in appraisal the skills of school counselor.

5) School counselor needs guidance in making evaluation instrument according to service program as planned before. 
6) Still confusing, needs to be operated with simpler and more specific formulas.

7) Requires to be given example of guidance and counseling evaluation based CIPP.

8) In order to make an easier analysis, the instrument should be made more specific and operational so it can be used as recommendation/follow up action.

9) CIPP model must be flexible for guidance and counseling service implementation and suitable with running curriculum (2013).

The test-drive of CIPP model effectivity should be done in several steps, they are pre test, socialization and training with 10 senior high schools in Semarang city which is followed by 15 school teacher in Semarang city and post test after school counselor done evaluating the guidance and counseling service which has been done in each school. The differences level of understanding toward guidance and counseling service evaluation in school was done using wilcoxon analysis and can be shown in following table:

Table 1 Wilcoxon Test Recapitulation

\begin{tabular}{ll}
\hline $\mathbf{Z}_{\text {calculation }}$ & $\mathbf{Z}_{\text {table }}$ in $\boldsymbol{\alpha}=\mathbf{5 \%}$ \\
\hline 3,18 & 1,96 \\
& $\mathrm{Z}_{\text {calculation }=3,18}>\mathrm{Z}_{\text {table }=1,96}$ \\
\hline
\end{tabular}

Based on wilcoxon analysis above, got Zcalculation 3,1, whereas $Z_{\text {table }}$ with $5 \%$ signification degree and $N=13$ got $Z_{\text {table }} 1,96$. So, the value $Z_{\text {calculation }}>Z_{\text {table }}\left(Z_{\text {calculation }}\right.$ is higher than $\left.Z_{\text {table }}\right)$, so it can be said if there is a difference between guidance and counseling service evaluation skill before and after receive the training of CIPP model. Therefore it can be concluded if evaluation model of guidance and counseling service based CIPP is effective to increase the competence in evaluating guidance and counseling service.

\subsection{Discussion}

The result of this research serves the attractive model regarding the implementation of guidance and counseling service evaluation in school. The experts and practicioners declared if the steps was already clear, suitable, expedotopis but lack in its operationality in a step of activity, so it needs to be more detailed what should the counselor do in each steps, method and its instrument so that school counselor can implement it easily. In order to make the evaluation is enabled to be implemented well, we need enough understanding regarding the technique and procedure of evaluation, endorser instrument and the complete form(Cobia \& Handerson, 2007). Therefore, the model developed along with the endorser instruments which is suitable with the circumstance of counselor itself.

Observed from CIPP evaluation models (context, input, process, product), the implementation of evaluation model based CIPP is arranged comprehensively, so the evaluation from counselor was not only concerned in requirements, process and result but it also needs system support. As CIPP model (Cobia \& Handerson, 2007, 2003), the evaluation is done to meet student requirements and the stakeholder whom involved in guidance and counseling service (context); school support in implementating guidance and counseling service and the pattern of program along with the implementation plans (input); the implementation process of guidance and counseling (process) and result from guidance and counseling service (product). Therefore the evaluation model development guidance and counseling service based on CIPP is arranged systematically completed with the manual about procedure and tools which enable counselor to develop its evaluation toward each management process in the same manner as explained in CIPP model.

Based on research results known as socialization and training of CIPP model were effective in increasing the counselor skill in evaluating guidance and counaeling service in school. The important research finding from this research is the accuracy of evaluation result. Almost half of subjects from counselor said if the evaluation result that they had done was accurate, whereas at about $15 \%$ of counselor said if the evaluation result was not accurate yet. These condition can be understood because the skill of counselor is different while doing the guidance and counseling evaluation so that the counselor who supported the resistance in evaluating guidance and counseling service based CIPP need refreshment and re-training. Therefore, from previous statements the usage of CIPP model as evaluation model has strategy value by showing the direction and implementation procedure guidance and counseling service evaluation accurately in each step of guidance and counseling management process (Stafflebeam, 2003).

The effectivity of evaluation result must be linked to accountability, so that it can be understood if the evaluation result which supporting the 
accountability can be upheld. When the evaluation result was very accurate, the counselor can uphold the accountability in guidance and counseling service by showing the competences and impacts of guidance and counseling service implementation (Sink, 2009). Thus counselor can explains accurately the importance of counseling profession in society. Then the result of follow up from this evaluation of guidance and counseling based on CIPP will enable the counselor to implement his duty optimally. Counselor can take a decision accurately about the changes that must be done to repair the quality of guidance and counseling service in school. Finally, the negative perspective from society about counselor such as counselor as school police, counseling is advice giving, counselor only caring the troubled student and so on (Munandir, 2005), is very possible to be decreased, or even diminished.

\section{CONCLUSION}

Based on research result and discussion above, several things can be concluded:

(1) The structure of evaluation model guidance and counseling in senior high school based on CIPP which is developed consists of: (a) rational (b) model concept (c) purposes (d) assumption (e) intervention target (f) steps (g) competence and role of school counselor (h) system support

(2) Evaluation model of guidance and counseling in senior high school based CIPP which developed is effective to increase the competence of counselor in evaluating guidance and counseling service.

Based on the conclussions above, the suggestions that can be offered is as follows:

(1) For the next research, supervision while doing the evaluation of guidance and counseling service based on CIPP is expected to be more intensive and the responsible party should enlarge the limited test-drive so that the evaluation of guidance and counseling service based CIPP can be implemented also for elementary and junior high school grade.

(2) For supervisor and school counselor, they need to have more understanding about the CIPP concept and developing instrument according to school requirements until evaluating guidance and counseling service can be optimally achieved.

\section{REFERENCES}

[1] Cobia, D.C., \& Handerson, D.A. 2003. Handbook of School Counseling. Upper Saddle River: Merrill Prentice Hall.

[2] Cobia, D.C., \& Handerson, D.A. 2007. Developing an Effective and Accountable School Counseling Program. Upper Saddle River: Merrill Prentice Hall.

[3] Fitzpatrick, J.L., Sanders, J.R., \& Worthen, B.R. 2004. Program Evaluation: Alternative Approach and Practical Guideline. Boston: Allyn and Bacon.

[4] Gall, M.D., Gall, J.P., \& Borg, W.R. 2007. Educational Research: An Introduction. Boston: Allyn \& Bacon.

[5] Gibson, R.L. \& Mitchell, M.H. 2008. Introduction to Counseling and Guidance. Diterjemahkan Y. Santoso. Yogyakarta: Pustaka Pelajar.

[6] Gysbers, N.C. 1995. Evaluating School Guidance Program. ERIC Digest. ED388887.

[7] Gysbers, N.C., \& Handerson, P. 2006. Developing and Managing Your School Guidance and Counseling Program. Alexandria: American Counseling Association.

[8] Munandir. 2005. Keliru Pengertian (Miskonsepsi) dan Malpraktik mengenai Bimbingan. Makalah disampaikan dalam Sertifikasi Tes bagi Konselor Sekolah di Universitas Negeri Malang, Malang, JuniAgustus 2005.

[9] Prayitno. 1987. Profesionalisasi Konseling dan Pendidikan Konselor. Jakarta: P2LPTK.

[10] Sugiyo. 2010. Faktor-faktor yang Berkontribusi terhadap Kepuasan Kerja dan Kinerja Konselor (Guru Pembimbing) di Sekolah.Pidato Pengukuhan Guru Besar Jurusan Bimbingan dan Konseling FIP Universitas Negeri Semarang, Semarang, 23 Februari 2010.

[11] Sugiyo. 2012. Pengembangan Model Evaluasi Pelayanan Bimbingan dan Konseling di Sekolah Menengah Atas (SMA) Berbasis CIPP. Laporan Penelitian Terapan tahap I.

[12] Sink, C.A. 2009. School Counselors as Accountability Leaders: Another Call For Action. Professional School Counseling. (online) Diunduh melalui www.findarticles.com pada tanggal 30 September 2010.

[13] Stafflebeam, D.L. 1999. Foundational Models for $21 \mathrm{st}$ CenturyProgram Evaluation. MakalahDisajikandalamSymposium atthe annual meeting of the American Educational Research Association; Montreal, Quebec, Canada; April 20, 1999.

[14] Stafflebeam, D.L. 2003. The CIPP Model for Evaluation. Dalam T. Kellaghan \& D.L. Stafflebeam. International Handbook of Educational Evaluation. Dordrecht: Kluwer Academic
Publishers. 